\title{
Allium Sativum Leaf Agglutinin (ASAL) Endowed Enhanced Resistance Against Myzus Persicae under Both Constitutive and Phloem Specific Promoters
}

Noroza Umer

National Institute for Biotechnology and Genetic Engineering

Rubab Zahra Naqvi

National Institute for Biotechnology and Genetic Engineering Imran Rauf

National Institute for Biotechnology and Genetic Engineering Naveed Anjum

National Institute for Biotechnology and Genetic Engineering Hamid Anees Siddiqui

National Institute for Biotechnology and Genetic Engineering

Syed Najeebullah

National Institute for Biotechnology and Genetic Engineering

\section{Shaheen Asad}

National Institute for Biotechnology and Genetic Engineering

Muhammad Asif ( $\square$ asif.biosafety@gmail.com)

National Institute for Biotechnology and Genetic Engineering https://orcid.org/0000-0001-5209-2953

\section{Research Article}

Keywords: Allium sativum leaf agglutinin, (ASAL), 35S constitutive promoter, rolC phloem specific promoter, Aphids (Myzus persicae), Transgenic tobacco

Posted Date: November 18th, 2021

DOI: https://doi.org/10.21203/rs.3.rs-1042830/v1

License: (9) (1) This work is licensed under a Creative Commons Attribution 4.0 International License. Read Full License 


\section{Abstract}

Globally, aphid, Myzus persicae is an economically significant, polyphagous crop pest that feeds on more than 400 plant species and transmits more than 100 plant viruses. Aphid infestation is mostly managed by insecticides that cause heavy environmental contamination and insect resistance. Cloning of plant derived insecticidal genes to develop transgenic plants under suitable promoter is a promising technology. In the present study, ASAL (MN820725) was isolated from native garlic and cloned in plant transformation vector, pGA482 through Agrobacterium mediated tobacco transformation. PCR of genomic DNA of transgenic tobacco plants using gene specific primers confirmed the presence of asal gene of $546 \mathrm{bp}$. To detect the integration of gene Southern blot analysis was conducted that revealed stable integration of asal gene while, gene expression was analyzed through qRT-PCR that showed variable expression of asa/ gene in transgenic tobacco plants. Efficacy of asal gene was evaluated through aphid bioassay. Aphid bioassay revealed that transgenic tobacco lines LS-17, LS-20, LR-1, and LR-7 exhibited $100 \%$ aphid mortality and significantly reduced the aphid population. These findings suggested the potential of ASAL against aphids that can be further used against other notorious sap sucking pests.

\section{Introduction}

Insect pest control has become a challenge for sustainable agriculture. Physical and molecular defense of plants have evolved against biotic and abiotic stress. Meanwhile, insect pests have also adopted themselves against defense system of plants (Napoleao et al. 2018). Although morphological and chemical defense of plants alter the preference (host plant selection, feeding behavior) and performance (growth and development) of insect complex (Furstenberg-Hagg et al. 2013) but still they are responsible for $40-50 \%$ qualitative and quantitative losses in crop plants. Sucking insect pest, aphid is a key pest that penetrate its stylet like mouth part into phloem tissue by probing through epidermis and mesophyll cells to drain free amino acids and amides of plants (Salman et al. 2011; Kaloshian and Walling 2016; Xu et al. 2019). Aphids are responsible of about $13 \%$ agricultural losses, globally. They can transmit about $50 \%$ plant-viruses as vector and secret honeydew that allow the growth of sooty molds on plant surface. Aphid feeding damages the strength of plants and stunt their growth. Growth of sooty mold covers the plant surface that retards the process of photosynthesis and distorts the plants (Will et al. 2007). In addition of short life cycle, female adults are capable to produce nymphs sexually, asexually or both (Dedryver et al. 2013). Aphid infestation triggers phosphorylation, calcium flux, and production of reactive oxygen species (ROS) that fluctuate the production of phyto-hormone and interrupt the transcriptional regulation of plants (Liang et al. 2015; Shah et al. 2017).

Different control strategies based on physical barriers, pesticides, biotic agents and host-plant resistance have been used to combat sucking pests (Shukla et al. 2016). Transgenic technology is an economical and environment friendly approach to manipulate host plant resistance and incorporate insecticidal genes in plants (Arora and Sandhu 2017). Allium sativum leaf agglutinin (ASAL) is a mannose-binding lectin that has been reported in garlic (Allium sativum). It targets sucking insect pests and binds to their 
glycosylated receptors including alkaline phosphatase (ALP), aminopeptidase-N (APN), cadherin-like proteins, polycalins, sucrase, symbionin, crosses the hemolymph and deposits in the ovarioles and/or in fat bodies. These processes disrupt the membrane integrity, inhibit feed digestion and retard nutrient absorption that ultimately lead towards insect mortality (Upadhyay and Singh 2012). It has been reported that deposition of ASAL in ovarioles of aphid retards circulation of nutrients that could reduce aphid's fecundity up to $74 \%$. Aphid fecundity is also reduced when ASAL binds with NADH quinone oxidoreductase (NQO), a key component of electron transport chain, insect defense response and gametogenesis (Roy et al. 2014). In present study, ASAL has been introduced in tobacco plants to confer resistance against aphids and other sucking insect pests. ASAL was isolated from garlic leaves and cloned in plant transformation vector, pGA482 for Agrobacterium mediated tobacco transformation. Expression of ASAL was achieved under 2X35S constitutive promoter and rolC phloem specific promoter to specifically target phloem feeders, aphids. Molecular characterization and aphid bioassay of transgenic tobacco plants revealed insecticidal effectivity of ASAL. These findings could be useful to develop environment friendly sucking-pest resistant crop varieties.

\section{Material And Methods}

\section{In-silico characterization of promoters and asal gene}

The cis-regulatory elements within the 2 X35S constitutive promoter and rolC phloem specific promoter were identified using PlantCARE software for comparative analysis (Lescot et al. 2002).

The nucleotide sequence of ASAL was translated through Swiss Bioinformatics Server (Artimo et al. 2012). Signal peptide and subcellular localization of protein was predicted by TargetP 1.1 Server (Emanuelsson et al. 2000). Molecular weight and isoelectric point of protein was computed using in-silico analysis (Gasteiger et al. 2005). Domain was predicted by online PROSITE scan tool (Sigrist et al. 2012). Protein structure was predicted by I-TASSER (Roy et al. 2010; Yang et al. 2015). Protein model having C-score $=-2.99$, Estimated TM-score $0.38 \pm 0.13$ and Estimated RMSD $=12.0 \pm 4.4 \AA$ was selected. Protein Model predicted by I-TASSER was submitted to ConSurf server (Ashkenazy et al. 2010; Ashkenazy et al. 2016) for prediction of evolutionary conserved residues. Phylogenetic analysis of ASAL was conducted by MEGA 6.0 (Maximum Likelihood) while Motif prediction in all the orthologues of ASAL was identified by Motif finder.

\section{Plant materials}

Bulblets of Allium sativum (garlic) were obtained from Ayub Agricultural Research Institute (AARI), Faisalabad, Pakistan and grew them in peat moss under control conditions at $27-28{ }^{\circ} \mathrm{C}$ and $54-67 \%$ relative humidity. Seeds of Nicotiana tabacum were sterilized with mixture of $20 \%$ chlorox plus, $0.02 \%$ Tween 20, rinsed with distilled water and dried to sow on Murashige and Skoog (MS) medium (Murashige and Skoog 1962) under aseptic conditions at $27-28^{\circ} \mathrm{C}$ and $54-67 \%$ relative humidity. 


\section{Construct development (35S-ASAL-CaMV and roIC-ASAL- CaMV)}

Total RNA was isolated from garlic using Plant RNA Purification Kit (Cat No.12322-012, Invitrogen) to synthesis cDNA using H-Minus First Strand cDNA Synthesis Kit (Cat No. K1632, Thermo Fisher) according to the manufacturer's protocol. Primers were designed in-silico using Primer3 program (Untergasser et al. 2012) to amplify full length asal gene from garlic. RT-PCR of $50 \mu \mathrm{l}$ reaction mixture was conducted using proofreading DNA polymerase, $p f u(2.5 \mathrm{U})$, and cDNA $(1 \mu \mathrm{g})$ to amplify 546 bp full length asal gene using $10 \mu \mathrm{M}$ of gene-specific primer pair, ASAL-F3 and ASAL-R3 (Table 1).

Reaction mixture was run in thermal cycler under following conditions; initial denaturation at $94^{\circ} \mathrm{C}$ for 5 min followed by 39 cycles of $94^{\circ} \mathrm{C}$ for $1 \mathrm{~min}, 63^{\circ} \mathrm{C}$ for $1 \mathrm{~min}, 72^{\circ} \mathrm{C}$ for $1 \mathrm{~min}$ and final extension of $72{ }^{\circ} \mathrm{C}$ for 5 min. Amplified gene was eluted using a Gel Extraction Kit (Cat No. K2100-12, Invitrogen) and cloned in PCR blunt cloning vector (Cat No. K2700-20, Invitrogen). Resulting clone was confirmed through restriction analysis and Sanger sequencing.

Full length asal gene was restricted from PCR blunt vector using HindIII and Smal and cloned in pJIT163 having 2 X35S promoter and CaMV terminator. Gene cassette, 35S-ASAL-CaMV was restricted from resulting plasmid pIT163-ASAL using SaCl and ECoRV and cloned in plant transformation vector, pGA482. The resulting plasmid, pGA482-35S-ASAL was confirmed through restriction analysis.

2X35S promoter of pIJT163 was replaced with rolC promoter to clone full length asal gene under phloem specific rolC promoter. Engineered gene cassette (rolC-ASAL-CaMV) was cloned in pGA482. The resulting plasmid, pGA482-rolC-ASAL was confirmed through restriction analysis.

\section{Agrobacterium mediated tobacco transformation}

Plasmids pGA482-35S-ASAL and pGA482-rolC-ASAL were separately, electroporated in Agrobacterium tumefaciens strain, LBA4404 and their cultures were developed. For stable transformation, leaf discs of Nicotiana tabacum (cv. Samsun) (Amaya 1997) were co-cultivated with engineered cultures of $A$. tumefaciens. and kept over the regeneration media containing MS salt and sucrose to develop transgenic tobacco plants..

\section{Molecular analysis of tobacco plants}

All putative transgenic tobacco plants were screened using gene specific and construct specific primer pairs (Table 1). CTAB (cetyl trimethylammonium bromide) method (Doyle and Doyle 1987) was used to isolate genomic DNA from leaves of tobacco plants expressing ASAL under $35 \mathrm{~S}$ and rolC promoters, respectively. PCR reaction mixture of $25 \mu \mathrm{l}$ was prepared using $100 \mathrm{ng}$ of DNA, $12.5 \mu \mathrm{l}$ of Dream Taq Green PCR Master Mix (2X) (Cat No. K1081, Thermo Scientific), and $1 \mu$ of each primer (10 $\mu \mathrm{M})$. Gene specific primers were used to confirm the presences of asa/gene while construct specific primers were 
used to detect the promoter-gene fragment (35S-ASAL or rolC-ASAL) in transgenic tobacco plants. PCR reaction mixture was run in thermal cycler at $94^{\circ} \mathrm{C}$ for 5 min followed by 35 cycles of $94^{\circ} \mathrm{C}$ for $1 \mathrm{~min}, 63^{\circ} \mathrm{C}$ for $1 \mathrm{~min}, 72^{\circ} \mathrm{C}$ for $1 \mathrm{~min}$ and final extension of $72^{\circ} \mathrm{C}$ for $5 \mathrm{~min}$. The PCR amplified products were checked on $1 \%$ agarose gel to screen transgenic tobacco plants.

Integration and copy number of transgene (asal) was detected in $\mathrm{T}_{0}$ tobacco lines through Southern blotting. For this genomic DNA was extracted from the transgenic tobacco expressing ASAL under $35 \mathrm{~S}$ and rolC promoters. DNA $(100 \mu \mathrm{g})$ samples were restricted using $E c o R I$ at $37^{\circ} \mathrm{C}$ overnight and then subjected to the electrophoresis using $0.8 \%$ agarose gel at 25 volts overnight. Fractionated DNA fragments were transferred to the positively charged nylon membrane. Nylon membrane was crosslinked with UV linker $\left(0.240 \mathrm{~J} / \mathrm{cm}^{2}\right)$ (Strata linker) and hybridized with DIG (digoxigenin) labelled probe. Nylon membrane was washed using Dig Wash and Blocking Buffer Set (Cat No.11585762001 Roche) and signals were developed using color substrate NBT/BCIP.

\section{qRT-PCR for gene expression analysis}

qRT-PCR was conducted for relative gene expression analysis of asa/gene in $\mathrm{T}_{0}$ transgenic tobacco lines. RNA was isolated from the 3-4 leaf stage (45 days old) transgenic and non-transgenic tobacco plants using SV Total RNA Isolation System (Cat No. Z3101, Promega). Primers were designed using Primer3 program. Concentration of primers were optimized, and qPCR reaction mixture was prepared containing, cDNA (200 ng), Power SYBR Green PCR Master Mix (Thermo Scientific), gene specific primers (qASAL-F5, qASAL-R5) and 18S rRNA as internal control (Table 1). Three replicates/sample were loaded on 96 well plate to run in Quantstudio 6 Real-time PCR system (Thermo Fisher Scientific) using following conditions; $95^{\circ} \mathrm{C}$ for $3 \mathrm{~min}, 39 \mathrm{cycles}$ at $95^{\circ} \mathrm{C}$ for $30 \mathrm{sec}, 56^{\circ} \mathrm{C}$ for $30 \mathrm{sec}$ and $72{ }^{\circ} \mathrm{C}$ for $50 \mathrm{sec}$. Relative gene expression of each transgenic tobacco line was measured with $\Delta \Delta \mathrm{Ct}$ method.

\section{Aphid bioassay}

A culture of a tobacco-adapted M. persicae strain (Ramsey et al. 2007; Ramsey and Jander 2008) leaves of tobacco lines, LS-15, LS-17, LS-18, LS-20, LS-21 and LS-25 expressing ASAL under 2X35S promoter and tobacco lines, LR-1, LR-3, LR-7, LR-10, and LR-12 expressing ASAL under the rolC promoter were placed on Petri plates containing $1 \%$ agar. Detached leaves of non-transgenic tobacco were set parallel to transgenic tobacco lines as control. Five adult aphids were released on each leaf of transgenic and nontransgenic plants. Mortality and fecundity of adult aphids were observed after every 24 hours for thirteen days.

\section{Statistical analysis}


Significant difference of relative gene expression was determined between transgenic and non-transgenic tobacco plants using ANOVA followed by LSD. Mann-Whitney Utests was used to calculate significant difference of mortality and fecundity between aphid feeding on transgenic and non-transgenic tobacco.

\section{Results}

\section{Cis-regulatory elements of promoters}

PlantCARE software identified several motifs in $35 \mathrm{~S}$ and rolC promoter sequence. Phytohormone responsive elements like auxin, methyl jasmonic acid and abscisic acid responsive elements were identified in both $35 \mathrm{~S}$ and rolC promoter. Light responsive elements were frequently found dispersed throughout the rolC promoter. The predicted regulatory elements of both promoters have been illustrated in Table 2.

\section{In-silico analysis of asal gene}

Signal peptide of ASAL consist of 30 residues and belongs to the secretary protein with Reliability Class 2. The theoretical weight of ASAL was estimated at $19.25 \mathrm{kDa}$ with an isoelectric point (pl) 9.05. PROSITE tool predicted bulb-type lectin domain in ASAL that spanned over 31-140 residues that is D-mannose specific domain and contains disulfide bond between 59 and 83 residues. ConSurf results estimated the evolutionary conservation of amino acid positions in ASAL protein molecule based on the phylogenetic relations between homologous sequences (Fig. 1A-B). The server results were predicted in the range of scale $1-9$, where scale 1 is highly variable and scale 9 is highly conserved. Besides the conservation scale, the server also predicts whether the amino acid is functional or structural or exposed or buried (Fig. 1C). Phylogenetic analysis revealed the homology of ASAL protein among different species of Allium and other related families of plant species (Fig. 1D).

\section{Construct development for plant transformation}

Full length asal gene of 546 bp was successfully cloned in plant transformation vector pGA482 under 2 X35 promter (Fig. 1E). Restriction analysis of resulting plasmid pGA482-35S-ASAL using HindIII produced two fragments (1.3 kb and $13.3 \mathrm{~kb}$ ), EcoRI produced two fragments ( $3.8 \mathrm{~kb}$ and $10.8 \mathrm{~kb}$ ), while Smal produced three fragments of 766 bp, 6.3 kb, 7.4 kb (Fig. 1E).

Successful cloning of full length asal gene of $546 \mathrm{bp}$ under rolC promoter in pGA482 confirmed in resulting plasmid pGA482-rolC-ASAL using Hindlll that produced two fragments (857 bp, and $13.8 \mathrm{~kb}$ ). Restriction with $\mathrm{Clal}$ linearized the plasmid while $\mathrm{Clal}$ and $\mathrm{Xbal}$ digestion produced two fragments of 1.33 kb, and 13.4 kb (Fig. 1F). 


\section{Molecular analysis of transgenic tobacco}

Gene specific primer (ASAL-F3, ASAL-R3) amplified full-length asalgene of 546 bp and construct-specific primer pair (35S-F1, ASAL-R3) amplified promoter-gene fragment of $643 \mathrm{bp}$ in transgenic tobacco lines LS-15, LS-17, LS-18, LS-20, LS-21, LS-25 expressing ASAL under 2X35S promoter. (Fig. 2A-B). PCR of transgenic tobacco lines expressing ASAL under rolC promoter using gene specific primers confirmed the presence of asa/ gene of 546 bp in tobacco lines LR-1, LR-3, LR-7, LR-10, LR-12 while, asa/ gene was not amplified in LR-8 and LR-9 (Fig. 3A). Promoter gene fragment (rolC-ASAL) of $1.3 \mathrm{~kb}$ was amplified in tobacco lines LR-1, LR-3, LR-7, LR-10, LR-12 using construct specific primer pair (Fig. 3B). Results of Southern blot analysis of $T_{0}$ transgenic tobacco lines LS-18, LS-21, LR-10, and LR-12 confirmed integration of transgene asal in host tobacco genome (Fig. 4).

Findings of qRT-PCR showed that each transgenic tobacco line had variable expression of ASAL under 35 S promoter. The maximum expression was observed in transgenic tobacco line, LS-21 followed by LS18, LS-15, LS-17, LS-25 and LS-20. Transgenic tobacco LS-21 has 1 fold, 1.2 folds, 4 folds, 6 folds and 16 folds higher gene expression than LS-18, LS-15, LS-17, LS-25 and LS-20 respectively (Fig. 5). Variable, relative gene expression was also observed in transgenic tobacco lines expressing ASAL under rolC promoter. Transgenic tobacco, LR-1 has 1.2 folds, 1.7 folds, 5.8 folds, 9.6 folds higher gene expression than LR-12, LR-10, LR-3 and LR-7, respectively (Fig. 6).

\section{Aphid bioassays}

Data of aphid bioassay revealed entomotoxic effect of ASAL expressed under 35 S promoter or rolC promoter. Survival and fecundity of adult aphids reduced during feeding on transgenic tobacco. Tobacco lines expressing ASAL under 35S showed considerable level of resistance against aphids than nontransgenic tobacco (Fig. 7A-7C). Tobacco lines LS-17 and LS-20 showed $100 \%$ aphid mortality while $80-$ $90 \%$ mortality was showed by LS-15, LS-18, LS-21 and LS-25 (Fig. 7D). Different transgenic lines showed lethal effects on aphids during different time interval. LS-18 showed aphid mortality after 48 hours while LS-21 showed aphid mortality after 72 hours. Expression of ASAL in transgenic tobacco under $35 \mathrm{~S}$ promoter also reduced the population of aphids and retarded the aphid fecundity. Transgenic tobacco lines showed up to $63 \%$ reduction in aphid fecundity than non-transgenic tobacco plants (Fig. 7E).

Transgenic tobacco lines expressing ASAL under rolC promoter showed significant resistance against aphids than non-transgenic tobacco (Fig. 8A-C). Results of bioassay revealed that tobacco lines, LR-1 and LR-7 showed $100 \%$ aphid mortality while transgenic lines, LR-3, LR-10 and LR-12 showed $50-70 \%$ aphid mortality (Fig. 8D). Aphid's fecundity reduced up to $78 \%$ on transgenic tobacco expressing ASAL under rolC promoter (Fig. 8E).

\section{Discussion}


Aphids are deleterious crop pest that drain off phloem sap, transmit plant viruses and secret honeydew that allow the growth of molds (Eid et al. 2018). Expression of insecticidal genes in transgenic plants is an effective strategy to control sap sucking insect pests. Lectins have emerged as promising and ecofriendly insecticidal proteins for the development of insect resistance crop plants. Lectins can tolerate proteolytic effect of insect mid gut and confer entomotoxic effect against sap sucking insect pests, aphids (Caccia et al. 2012). In present study we have evaluated the efficacy of a mannose binding lectin, ASAL under 2 X35S constitutive promoter and rolC phloem specific promoter.

Choice of promoter is an effective criterion to achieve higher expression levels of a gene in transgenic plants (Hu et al. 2003). In the present study, we used 2X35 and rolC promoter to drive the expression of asal gene in transgenic tobacco plants. In silico study detected different cis-acting elements in both promotes. Presence of core transcriptional, metabolism, light responsive, temperature and phytohormones related cis-elements in 2X35S promoter showed its constitutive nature as studied earlier (Kay et al. 1987; Lam 1994; Benfey et al. 1990). Several cis-acting elements detected in the promoters of 2X35 and rolC were common. However, light responsive elements like AT1-motif, Box 4, Box II, LAMP element, Pc-CMA2c, and Sp1 were abundant in rolc promoter. It is reported that phloem tissues require light energy for conductivity of sap (Epron et al. 2019), therefore frequent distribution of light responsive elements in rolC sequence might contribute towards the phloem specificity of this promoter. The presence of these motifs and a canonical 13bp element phloem specific signatures in rolC promoter is in agreement with another study where they characterized rolC promoter using motif-based approach combined by EMSA (Saha et al. 2007). Moreover, phloem specific motifs found here in rolC promoter are concurrent with the previous studies of tissue specific promoters characterization (Hehn and Rohde 1998; Srivastava et al. 2014).

Allium sativum leaf agglutinin (ASAL) is a mannose-binding lectin having potent insecticidal activity against sucking complex as well as bollworms (Ghosh et al. 2016). Previous studies have reported $50 \%$ hydrophobic nature of signal peptide of ASAL that allows its synthesis on endoplasmic reticulum and follows the secretory pathway (Damme et al. 1998). Our results of ConSurf model (Fig. 1A-D) prediction also indicated $50 \%$ part of signal peptide is exposed (hydrophilic) while $50 \%$ part is embedded (hydrophobic) while subcellular localization of ASAL through TargetP 1.1 indicated its secretory nature. In-silico analysis of asal gene predicted N-terminal signal peptide and B-type lectin domain. The degree to which an amino acid position is evolutionarily conserved is strongly dependent on its structural and functional importance. Thus, conservation analysis of positions among members from the same family often revealed the importance of each position for the protein's structure or function. Lectin engineering could be used to enhance their toxicity and spectra (Van Holle et al. 2017; Hu et al. 2015; Bendre et al. 2018). Phylogenetic analysis revealed that ASAL and its orthologue are from important spice, ornamental and medicinal plants. So, it is inferred that ASAL lectin might have evolutionary importance for plant's own defense against insect-pests. Moreover, due to distribution of this ASAL and other lectin proteins in mostly edible and medicinally important crops may show its safe history. This indicates that ASAL and its homologs are used safely to develop transgenic plants. The phylogenetic analysis revealed that the translated asal is related to B-lectin family and present across different families in the plant kingdom and 
may have a widespread defensive role against pest-complex. A bulb lectin super-family (Amaryllidaceae, Orchidaceae and Aliaceae) contains a $~ 115$ residue long domain. Each bulb-type lectin domain consists of three sequential $\beta$-sheet subdomains (I, II, III) that are inter-related by pseudo three-fold symmetry.

Tobacco lines expressing 35S-ASAL and rolC-ASAL were developed through Agrobacterium mediated transformation. ASAL expression levels in transgenic tobacco plants were considerably high as indicated by aphid bioassays. Tobacco lines, expressing ASAL under 35S promoter and rolC promoter showed considerable aphidicidal effects. It is reported that mannose binding lectin, Galanthus navlis agglutinin (GNA) showed equivalent insecticidal effects against sap sucking pests under both constitutive and phloem specific promoter (Rao et al. 1998). Earlier findings suggested that ASAL under 35S constitutive promoter and rolC phloem specific promoter showed less or more equivalent rate of mortality and reduction in fecundity of sap sucking insect pests (Chakraborti et al. 2009). Our study also supported the similar results as we found that expression of ASAL in transgenic tobacco caused significant aphid mortality and reduced aphid fecundity during aphid bioassays. Maximum tobacco lines (LS-17, LS-20, LR-1 and LR-7) showed up to $100 \%$ aphid mortality and reduced aphid fecundity up to $78 \%$.

qRT-PCR is a sensitive and quick approach to detect the expression of transgene. Results of qRT-PCR on showed variable expression of ASAL among different tobacco lines. Such variations in gene expression level have already been reported due to accumulation of variable level of transcripts in plants. This difference in level of gene expression and accumulation of transcript may due to positional effect of integrated transgene. It may cause detrimental effect on transgene expression. In tobacco lines, LS-17, LS-20, LS-25, LR-3 and LR-7 inverse relationship was observed between expression and resistance against aphid. Recombination and DNA methylation of transgene could affect the colinear relationship between gene expression and its resistance (Naqvi et al. 2017).

Copy number of selected transgenic tobacco lines were detected using southern blot analysis. Hybridization bands of $>3.5 \mathrm{~kb}$ was detected in transgenic tobacco lines, LS-15, LS-18 and LS-21, harboring ASAL under 35S promoter and transgenic lines, LR-10 and LR-12 harboring ASAL under rolC promoter that reveled the stable integration of asal gene in each tobacco line. Presence of single hybridization band represented integration of single copy of T-DNA into tobacco genome. Single copy transgene integration in $T_{0}$ generation caused segregation of transgene in $T_{1}$ generation according to Mendelian inheritance (3:1) (Travella et al. 2005). Transgenic plants having single copy of introducing gene could preferably selected in breeding programs to develop commercialized varieties of plants. While, integration of multiple copy of T-DNA on single or multiple locus of host genome could be associated with co-suppression, non-Mendelian inheritance and instability of the transgenes (Matzke and Matzke 1998).

In the present study, the expression of ASAL was achieved under 35S promoter and rolC promoter to evaluate the efficiency of both promoters. It was found that irrespective to the type of promoters the expression and efficiency of ASAL was equivalent effective against aphids. Previous studies reported that expression of transgene under constitutive promoter could be high and/or equivalent to phloem specific 
promoter (Nakasu et al. 2014). It is also reported that mannose binding lectins expressing under both constitutive and phloem specific promoter showed equivalent insecticidal activity against sap sucking pests (Saha et al. 2007). Therefore, we conclude that ASAL expressed under both 2X35S and rolC promoters could be used for transformation of other crops. Furthermore, ASAL could be used in combination with other insecticidal genes for durable and sustainable insect pest control.

\section{Conclusions}

Evaluation of ASAL (MN820725) under 35S and rolC promoter, respectively revealed its entomotoxicity against aphid, Myzus persicae. Results of qRT-PCR verified significant expression of ASAL in transgenic tobacco lines. While, aphid bioassay reconnoitered that expression of ASAL in tobacco lines LS-17, LS-20, LR-1, LR-7 caused up to $100 \%$ aphid mortality and reduced their fecundity than control tobacco. These findings suggested the potential of ASAL that could be effectively used to engineer insect resistant crop varieties against various sucking insect pests.

\section{Abbreviations}

ASAL: Allium sativum leaf agglutinin, CTAB: Cetyl trimethylammonium bromide, PCR: Polymerase chain reaction, qRT: Quantitative reverse transcriptase, kb: kilo bites, bp: Base pair, kDa: kilo Dalton

\section{Declarations}

\section{Acknowledgements}

We would like to thank Dr. Nasir Ahmad Saeed, DCS, NIBGE for providing the rolC promoter. This research was supported through a grant from Higher Education Commission HEC- NRPU Project No. 8087 (Principal investigator, Dr. Muhammad Asif) and International Research Support Initiative Program (IRSIP) of HEC. Part of this research work was conducted in Georg Jander lab, BTI, USA during IRSIP visit of Noroza Umer.

\section{Funding}

This research was funded by a grant from International Research Support Initiative Program of Higher Education Commission (HEC) of Pakistan, HEC- NRPU Project No. 8087 (Principal investigator, Dr. Muhammad Asif).

\section{Conflict of interest}

Authors declare that they have no conflict of interest. 


\section{Availability of data and material}

Not applicable

\section{Code availability}

Not applicable

\section{Author contributions}

MA conceived and supervised this study. NU, MA and RZN were involved in designing the constructs and vectors. NU performed all the cloning experiments, analyzed data, interpreted the results, and wrote first draft of this manuscript. NA and HAS performed in silico analysis and its interpretation. NU and IR conducted aphid bioassays and analyzed the results. NU and RZN analyzed and interpreted qRT-PCR data. MA keenly revised and shaped the final manuscript. SA and SN participated in tissue culture experiments and gave their suggestions and recommendations in this regard.

\section{Ethics approval}

Not applicable

\section{Consent to participate}

Not applicable

\section{Consent for publication}

All authors are agree to submit this publication

\section{References}

1. Amaya I (1997) Tobacco Agrobacterium-mediated Transformation Protocol. Laboratories of PM Hasegawa and RA Bressan, West Lafayette, IN 47907-1165

2. Arora R, Sandhu S (2017) Breeding Insect Resistant Crops for Sustainable Agriculture. Springer Singapore. 1st edn.doi:10.1007/978-981-10-6056-4

3. Artimo P, Jonnalagedda M, Arnold K, Baratin D, Csardi G, De Castro E, Duvaud S, Flegel V, Fortier A, Gasteiger E (2012) ExPASy: SIB bioinformatics resource portal. Nucleic Acids Res 40(W1):597-603 
4. Ashkenazy H, Abadi S, Martz E, Chay O, Mayrose I, Pupko T, Ben-Tal N (2016) ConSurf 2016: an improved methodology to estimate and visualize evolutionary conservation in macromolecules. Nucleic Acids Res 44(W1):344-350

5. Ashkenazy H, Erez E, Martz E, Pupko T, Ben-Tal N (2010) ConSurf 2010: calculating evolutionary conservation in sequence and structure of proteins and nucleic acids. Nucleic Acids Res 38(suppl2):529-533

6. Bendre AD, Ramasamy S, Suresh CG (2018) Analysis of Kunitz inhibitors from plants for comprehensive structural and functional insights. Int J Biol Macromol 113:933-943. doi:https://doi.org/10.1016/j.ijbiomac.2018.02.148

7. Benfey PN, Ren L, Chua N-H (1990) Tissue-specific expression from CaMV 35 S enhancer subdomains in early stages of plant development. EMBO J 9(6):1677-1684

8. Caccia S, Van Damme EJ, De Vos WH, Smagghe G (2012) Mechanism of entomotoxicity of the plant lectin from Hippeastrum hybrid (Amaryllis) in Spodoptera littoralis larvae. J Insect Physiol 58(9):1177-1183

9. Chakraborti D, Sarkar A, Mondal HA, Das S (2009) Tissue specific expression of potent insecticidal, Allium sativum leaf agglutinin (ASAL) in important pulse crop, chickpea (Cicer arietinum $\mathrm{L}$.) to resist the phloem feeding Aphis craccivora. Transgenic Res 18(4):529-544

10. Damme EJV, Peumans WJ, Barre A, Rouge P (1998) Plant lectins: a composite of several distinct families of structurally and evolutionary related proteins with diverse biological roles. Crit Rev Plant Sci 17(6):575-692

11. Dedryver CA, Le Gallic JF, Maheo F, Simon JC, Dedryver F (2013) The genetics of obligate parthenogenesis in an aphid species and its consequences for the maintenance of alternative reproductive modes. Heredity 110(1):39

12. Doyle J, Doyle J (1987) A rapid DNA isolation procedure for small quantities of fresh leaf tissue. Proc Natl Acad Sci USA 89:7722-7726

13. Eid A, El-Heneidy A, Hafez A, Shalaby F, Adly D (2018) On the control of the cotton aphid, Aphis gossypii Glov.(Hemiptera: Aphididae), on cucumber in greenhouses. Egypt Journal Biol Pest Co 28(1):64

14. Emanuelsson O, Nielsen H, Brunak S, Von Heijne G (2000) Predicting subcellular localization of proteins based on their N-terminal amino acid sequence. J Mol Biol 300(4):1005-1016

15. Epron D, Dannoura M, Holtta T (2019) Introduction to the invited issue on phloem function and dysfunction. Tree Physiol 39(2):167-172. doi:10.1093/treephys/tpz007

16. Furstenberg-Hagg J, Zagrobelny M, Bak S (2013) Plant defense against insect herbivores. Int J Mol Sci 14(5):10242-10297

17. Gasteiger E, Hoogland C, Gattiker A, Wilkins MR, Appel RD, Bairoch A (2005) Protein Identification and Analysis Tools on the ExPASy Server. The Proteomics Protocols Handbook. Springer, pp 571-607

18. Ghosh P, Sen S, Chakraborty J, Das S (2016) Monitoring the efficacy of mutated Allium sativum leaf lectin in transgenic rice against Rhizoctonia solani. BMC Biotechnol 16(1):24 
19. Hehn A, Rohde W (1998) Characterization of cis-acting elements affecting strength and phloem specificity of the coconut foliar decay virus promoter. J Gen Virol 79(6):1495-1499

20. Hu D, Tateno H, Hirabayashi J (2015) Lectin engineering, a molecular evolutionary approach to expanding the lectin utilities. Molecules 20(5):7637-7656

21. Hu Y, Chen B, Ni T, Li N, Lin Z (2003) Promoter of the rolC gene of Agrobacterium rhizogenes can be strongly regulated in glandular cell of transgenic tobacco. Mol Biotechnol 24(2):121-125

22. Kaloshian I, Walling LL (2016) Hemipteran and dipteran pests: effectors and plant host immune regulators. J Integr Plant Biol 58(4):350-361

23. Kay R, Chan A, Daly M, McPherson J (1987) Duplication of CaMV 35S promoter sequences creates a strong enhancer for plant genes. Science 236(4806):1299-1302

24. Lam E (1994) Analysis of tissue-specific elements in the CaMV 35 S promoter. Plant promoters and transcription factors. Springer, pp 181-196

25. Lescot M, Déhais P, Thijs G, Marchal K, Moreau Y, Van de Peer Y, Rouzé P, Rombauts S (2002) PlantCARE, a database of plant cis-acting regulatory elements and a portal to tools for in silico analysis of promoter sequences. Nucleic Acids Res 30(1):325-327

26. Liang D, Liu M, Hu Q, He M, Qi X, Xu Q, Zhou F, Chen X (2015) Identification of differentially expressed genes related to aphid resistance in cucumber (Cucumis sativus L.). Sci Rep 5:9645

27. Matzke AJ, Matzke MA (1998) Position effects and epigenetic silencing of plant transgenes. Curr Opin Plant Biol 1(2):142-148

28. Murashige T, Skoog $F$ (1962) A revised medium for rapid growth and bio assays with tobacco tissue cultures. Physiol Plant 15(3):473-497. doi:https://doi.org/10.1111/j.1399-3054.1962.tb08052.x

29. Nakasu EY, Edwards MG, Fitches E, Gatehouse JA, Gatehouse AM (2014) Transgenic plants expressing $\omega$-ACTX-Hv1a and snowdrop lectin (GNA) fusion protein show enhanced resistance to aphids. Front Plant Sci 5:673

30. Napoleao TH, Albuquerque LP, Santos ND, Nova IC, Lima TA, Paiva PM, Pontual EV (2018) Insect midgut structures and molecules as targets of plant-derived protease inhibitors and lectins. Pest Manag Sci 75(5):1212-1222. doi: https://doi.org/10.1002/ps.5233

31. Naqvi RZ, Asif M, Saeed M, Asad S, Khatoon A, Amin I, Mukhtar Z, Bashir A, Mansoor S (2017) Development of a triple gene Cry1Ac-Cry2Ab-EPSPS construct and its expression in Nicotiana benthamiana for insect resistance and herbicide tolerance in plants. Front Plant Sci 8:55

32. Ramsey JS, Jander G (2008) Testing nicotine tolerance in aphids using an artificial diet experiment. J Vis Exp 15:e701

33. Ramsey JS, Wilson AC, de Vos M, Sun Q, Tamborindeguy C, Winfield A, Malloch G, Smith DM, Fenton B, Gray SM (2007) Genomic resources for Myzus persicae: EST sequencing, SNP identification, and microarray design. BMC Genomics 8(1):423

34. Rao K, Rathore KS, Hodges TK, Fu X, Stoger E, Sudhakar D, Williams S, Christou P, Bharathi M, Bown DP (1998) Expression of snowdrop lectin (GNA) in transgenic rice plants confers resistance to rice 
brown planthopper. Plant J 15(4):469-477

35. Roy A, Gupta S, Hess D, Das KP, Das S (2014) Binding of insecticidal lectin Colocasia esculenta tuber agglutinin (CEA) to midgut receptors of Bemisia tabaciand Lipaphis erysimi provides clues to its insecticidal potential. Proteomics 14(13-14):1646-1659

36. Roy A, Kucukural A, Zhang Y (2010) I-TASSER: a unified platform for automated protein structure and function prediction. Nat Protoc 5(4):725

37. Saha P, Chakraborti D, Sarkar A, Dutta I, Basu D, Das S (2007) Characterization of vascular-specific RSs 1 and rolC promoters for their utilization in engineering plants to develop resistance against hemipteran insect pests. Planta 226(2):429-442

38. Salman M, Masood A, Arif M, Saeed S, Hamed M (2011) The resistance levels of different cotton varieties against sucking insect pests complex in Pakistan. Pak J Agric Eng Vet Sci 27:168-175

39. Shah FM, Razaq M, Ali A, Han P, Chen J (2017) Comparative role of neem seed extract, moringa leaf extract and imidacloprid in the management of wheat aphids in relation to yield losses in Pakistan. PLoS ONE 12(9):e0184639

40. Shukla AK, Upadhyay SK, Mishra M, Saurabh S, Singh R, Singh H, Thakur N, Rai P, Pandey P, Hans AL (2016) Expression of an insecticidal fern protein in cotton protects against whitefly. Nature Biotechnol 34(10):1046

41. Sigrist CJ, De Castro E, Cerutti L, Cuche BA, Hulo N, Bridge A, Bougueleret L, Xenarios I (2012) New and continuing developments at PROSITE. Nucleic Acids Res 41(D1):344-347

42. Srivastava VK, Raikwar S, Tuteja N (2014) Cloning and functional characterization of the promoter of PSSEOF1 gene from Pisum sativum under different stress conditions using Agrobacterium-mediated transient assay. Plant Signal Behav 9(9):e29626

43. Travella S, Ross S, Harden J, Everett C, Snape J, Harwood W (2005) A comparison of transgenic barley lines produced by particle bombardment and Agrobacterium-mediated techniques. Plant Cell Rep 23(12):780-789

44. Untergasser A, Cutcutache I, Koressaar T, Ye J, Faircloth BC, Remm M, Rozen SG (2012) Primer3-new capabilities and interfaces. Nucleic Acids Res 40(15):115-116

45. Upadhyay SK, Singh PK (2012) Receptors of garlic (Allium sativum) lectins and their role in insecticidal action. Protein J 31(6):439-446

46. Van Holle S, De Schutter K, Eggermont L, Tsaneva M, Dang L, Van Damme E (2017) Comparative study of lectin domains in model species: new insights into evolutionary dynamics. Int J Mol Sci 18(6):1136

47. Will T, Tjallingii WF, Thonnessen AvB, Aart JE (2007) Molecular sabotage of plant defense by aphid saliva. Proc Natl Acad Sci USA 104(25):10536-10541

48. Xu HX, Qian LX, Wang XW, Shao RX, Hong Y, Liu SS, Wang XW (2019) A salivary effector enables whitefly to feed on host plants by eliciting salicylic acid-signaling pathway. Proc Natl Acad Sci USA 116(2):490-495 
49. Yang J, Yan R, Roy A, Xu D, Poisson J, Zhang Y (2015) The I-TASSER Suite: protein structure and function prediction. Nat Methods 12(1):7

\section{Tables}

\section{Table 1}

Primers used for cloning, PCR and qRT-PCR

\begin{tabular}{|ll|}
\hline Prime name & Primer sequence 5- 3 \\
\hline $35 S-F 1$ & CTGACGTAAGGGATGACGCAC \\
\hline rolC-F2 & ATCGATGCGAAAGCGGCATTGGCAAA \\
\hline ASAL-F3 & AAGCTTATGGGTCCTACTACTTCATC \\
\hline ASAL-R3 & GAATTCTCAAGCAGCACCGGTGCCAA \\
\hline qASAL-F5 & CCAATCACTGGATGTAGAACA \\
\hline qASAL-R5 & CGTCCGTTAACATCGTAGA \\
\hline 18S-F6 & GTGGTGCATGGCCGTTCTTA \\
\hline 18S-R6 & AACTTCCGCGGCCTAAAAGG \\
\hline
\end{tabular}

Table 2

Cis-acting elements associated with $35 \mathrm{~S}$ promoter and rolC promoter 


\begin{tabular}{|c|c|c|c|c|c|}
\hline Promoter & $\begin{array}{l}\text { Motif } \\
\text { name }\end{array}$ & Organism & Position & Sequence & Function \\
\hline \multirow[t]{9}{*}{$\begin{array}{l}\text { Cis-acting elements } \\
\text { found common in } \\
\text { both } 35 \mathrm{~S} \text { and rolC } \\
\text { promoter }\end{array}$} & ABRE & $\begin{array}{l}\text { Arabidopsis } \\
\text { thaliana }\end{array}$ & 610 & ACGTG & $\begin{array}{l}\text { cis-acting } \\
\text { element } \\
\text { involved in the } \\
\text { abscisic acid } \\
\text { responsiveness }\end{array}$ \\
\hline & $\begin{array}{l}\text { CAAT } \\
\text { box }\end{array}$ & $\begin{array}{l}\text { Nicotiana } \\
\text { glutinosa }\end{array}$ & 60 & CAAT & $\begin{array}{l}\text { common cis- } \\
\text { acting element } \\
\text { in promoter } \\
\text { and enhancer } \\
\text { regions }\end{array}$ \\
\hline & $\begin{array}{l}\text { CGTCA } \\
\text { motif }\end{array}$ & $\begin{array}{l}\text { Hordeum } \\
\text { vulgare }\end{array}$ & 436 & CGTCA & $\begin{array}{l}\text { cis-acting } \\
\text { regulatory } \\
\text { element } \\
\text { involved in the } \\
\text { MeJA- } \\
\text { responsiveness }\end{array}$ \\
\hline & $\begin{array}{l}\text { DRE } \\
\text { box }\end{array}$ & $\begin{array}{l}\text { Arabidopsis } \\
\text { thaliana }\end{array}$ & 98 & GCCGAC & $\begin{array}{l}\text { dehydration } \\
\text { responsive } \\
\text { element }\end{array}$ \\
\hline & G box & Zea mays & 610 & CACGTC & $\begin{array}{l}\text { cis-acting } \\
\text { regulatory } \\
\text { element } \\
\text { involved in } \\
\text { light } \\
\text { responsiveness }\end{array}$ \\
\hline & G box & Zea mays & 271 & CACGTC & $\begin{array}{l}\text { cis-acting } \\
\text { regulatory } \\
\text { element } \\
\text { involved in } \\
\text { light } \\
\text { responsiveness }\end{array}$ \\
\hline & $\begin{array}{l}\text { TATA } \\
\text { box }\end{array}$ & $\begin{array}{l}\text { Arabidopsis } \\
\text { thaliana }\end{array}$ & 700 & TATATA & $\begin{array}{l}\text { core promoter } \\
\text { element } \\
\text { around }-30 \text { of } \\
\text { transcription } \\
\text { start }\end{array}$ \\
\hline & $\begin{array}{l}\text { TGA } \\
\text { box }\end{array}$ & $\begin{array}{l}\text { Brassica } \\
\text { oleracea }\end{array}$ & 766 & AACGAC & $\begin{array}{l}\text { auxin- } \\
\text { responsive } \\
\text { element }\end{array}$ \\
\hline & $\begin{array}{l}\text { TGACG } \\
\text { box }\end{array}$ & $\begin{array}{l}\text { Hordeum } \\
\text { vulgare }\end{array}$ & 436 & TGACG & $\begin{array}{l}\text { cis-acting } \\
\text { regulatory } \\
\text { element } \\
\text { involved in the } \\
\text { MeJA- } \\
\text { responsiveness }\end{array}$ \\
\hline $\begin{array}{l}\text { Cis-acting elements } \\
\text { found in } 35 \mathrm{~S}\end{array}$ & $\begin{array}{l}\text { AuxRR- } \\
\text { bov }\end{array}$ & $\begin{array}{l}\text { Nicotiana } \\
\text { tabacum }\end{array}$ & 222 & GGTCCAT & $\begin{array}{l}\text { cis-acting } \\
\text { regulatory }\end{array}$ \\
\hline
\end{tabular}


element

involved in auxin

responsiveness

\begin{tabular}{|c|c|c|c|c|}
\hline LTR & $\begin{array}{l}\text { Hordeum } \\
\text { vulgare }\end{array}$ & 72 & CCGAAA & $\begin{array}{l}\text { cis-acting } \\
\text { element } \\
\text { involved in low- } \\
\text { temperature } \\
\text { responsiveness }\end{array}$ \\
\hline LTR & $\begin{array}{l}\text { Hordeum } \\
\text { vulgare }\end{array}$ & 411 & CCGAAA & $\begin{array}{l}\text { cis-acting } \\
\text { element } \\
\text { involved in low- } \\
\text { temperature } \\
\text { responsiveness }\end{array}$ \\
\hline O2 site & Zea mays & 112 & $\begin{array}{l}\text { GATGA(C/T) } \\
(\mathrm{A} / \mathrm{G}) \mathrm{TG}(\mathrm{A} / \mathrm{G})\end{array}$ & $\begin{array}{l}\text { cis-acting } \\
\text { regulatory } \\
\text { element } \\
\text { involved in zein } \\
\text { metabolism } \\
\text { regulation }\end{array}$ \\
\hline O2 site & Zea mays & 451 & $\begin{array}{l}\text { GATGA(C/T) } \\
(\mathrm{A} / \mathrm{G}) \mathrm{TG}(\mathrm{A} / \mathrm{G})\end{array}$ & $\begin{array}{l}\text { cis-acting } \\
\text { regulatory } \\
\text { element } \\
\text { involved in zein } \\
\text { metabolism } \\
\text { regulation }\end{array}$ \\
\hline
\end{tabular}

$\begin{array}{lllll}\text { Cis-acting elements } & \text { A-box } & \text { Petroselinum } 147 & \text { CCGTCC } & \text { cis-acting }\end{array}$ found in rolC promoter crispum

\begin{tabular}{|c|c|}
\hline ARE & Zea mays \\
\hline
\end{tabular}

regulatory element

cis-acting regulatory element essential for the anaerobic induction

\begin{tabular}{|c|c|c|c|c|}
\hline AT1 & $\begin{array}{l}\text { Solanum } \\
\text { tuberosum }\end{array}$ & 457 & AATTATTTTTTATT & $\begin{array}{l}\text { part of a light } \\
\text { responsive } \\
\text { module }\end{array}$ \\
\hline Box 4 & $\begin{array}{l}\text { Petroselinum } \\
\text { crispum }\end{array}$ & 85 & ATTAAT & $\begin{array}{l}\text { part of a } \\
\text { conserved DNA } \\
\text { module } \\
\text { involved in } \\
\text { light } \\
\text { responsiveness }\end{array}$ \\
\hline Box 4 & $\begin{array}{l}\text { Petroselinum } \\
\text { crispum }\end{array}$ & 702 & ATTAAT & $\begin{array}{l}\text { part of a } \\
\text { conserved DNA } \\
\text { module } \\
\text { involved in } \\
\text { light } \\
\text { responsiveness }\end{array}$ \\
\hline
\end{tabular}




\begin{tabular}{lllll|}
\hline Boxll & $\begin{array}{l}\text { Solanum } \\
\text { tuberosum }\end{array}$ & 223 & TGGTAATAA & $\begin{array}{l}\text { part of a light } \\
\text { responsive } \\
\text { element }\end{array}$ \\
\hline $\begin{array}{l}\text { LAMP } \\
\text { element }\end{array}$ & $\begin{array}{l}\text { Pinacia } \\
\text { oleracea }\end{array}$ & 204 & CCTTATCCA & $\begin{array}{l}\text { light } \\
\text { responsive } \\
\text { element }\end{array}$ \\
\hline $\begin{array}{l}\text { PC- } \\
\text { CMA2C }\end{array}$ & $\begin{array}{l}\text { Pisum } \\
\text { sativum }\end{array}$ & 282 & GCCCACGCA & $\begin{array}{l}\text { light } \\
\text { responsive } \\
\text { element }\end{array}$ \\
\hline Sp1 & Oryza sativa & 287 & GGGCGG & $\begin{array}{l}\text { light } \\
\text { responsive } \\
\text { element }\end{array}$ \\
\hline $\begin{array}{l}\text { TATC- } \\
\text { box }\end{array}$ & Oryza sativa & 387 & TATCCCA & $\begin{array}{l}\text { cis-acting } \\
\text { element } \\
\text { involved in } \\
\text { gibberellin- } \\
\text { responsiveness }\end{array}$ \\
\hline $\begin{array}{l}\text { 13 bp } \\
\text { element }\end{array}$ & $\begin{array}{l}\text { Nicotiana } \\
\text { tabacum }\end{array}$ & 405 & TTAAGAGACCCTA & $\begin{array}{l}\text { Cis-acting } \\
\text { element } \\
\text { involved in } \\
\text { phloem } \\
\text { specificity }\end{array}$ \\
\hline
\end{tabular}

Figures 


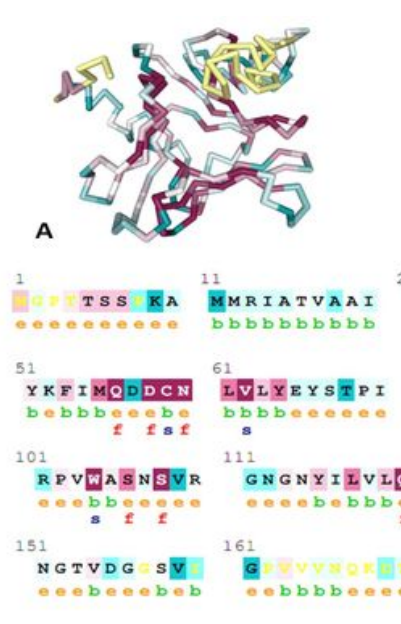

c
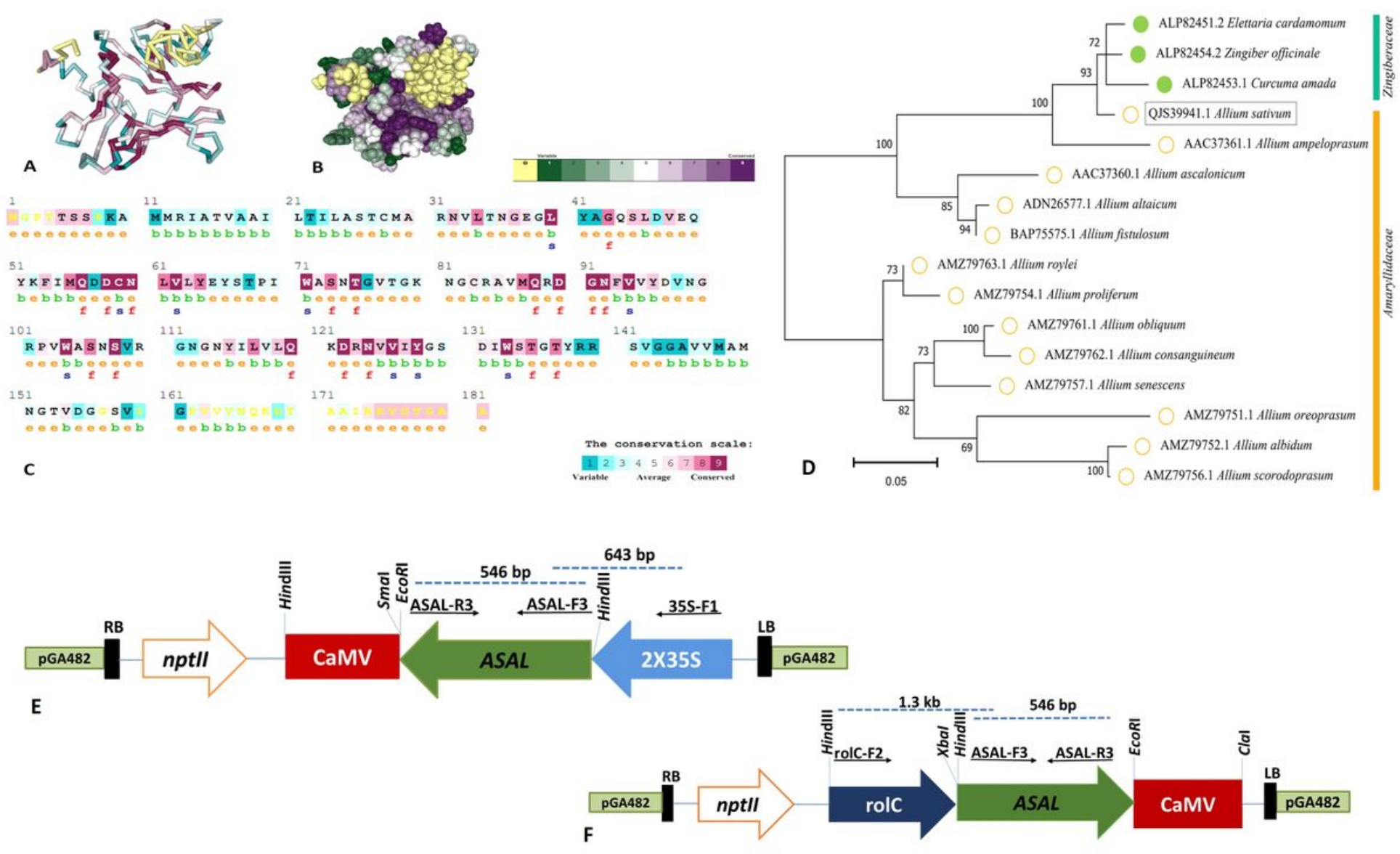

\section{Figure 1}

In-silico analysis and vector map of ASAL under 2X35S and rolC promoter in pGA482. (A) ConSurf analysis for the ASAL predicted backbone style, (B) space fill style, (C): The amino-acids are colored by their conservation grades using the color coding bar, e: Exposed residue, b: Buried residue, f: Predicted functional residue, s: Predicted structural residue, $X$ : Insufficient data (D) Phylogenetic analysis of ASAL protein and its orthologous from different species. (E)Vector map of plasmid pGA482-35S-ASAL to represent cloning of asal gene under 35 S promoter in pGA482. (F) Vector map of plasmid pGA482-rolCASAL to represent cloning of asal gene under rolC promoter in pGA482. 


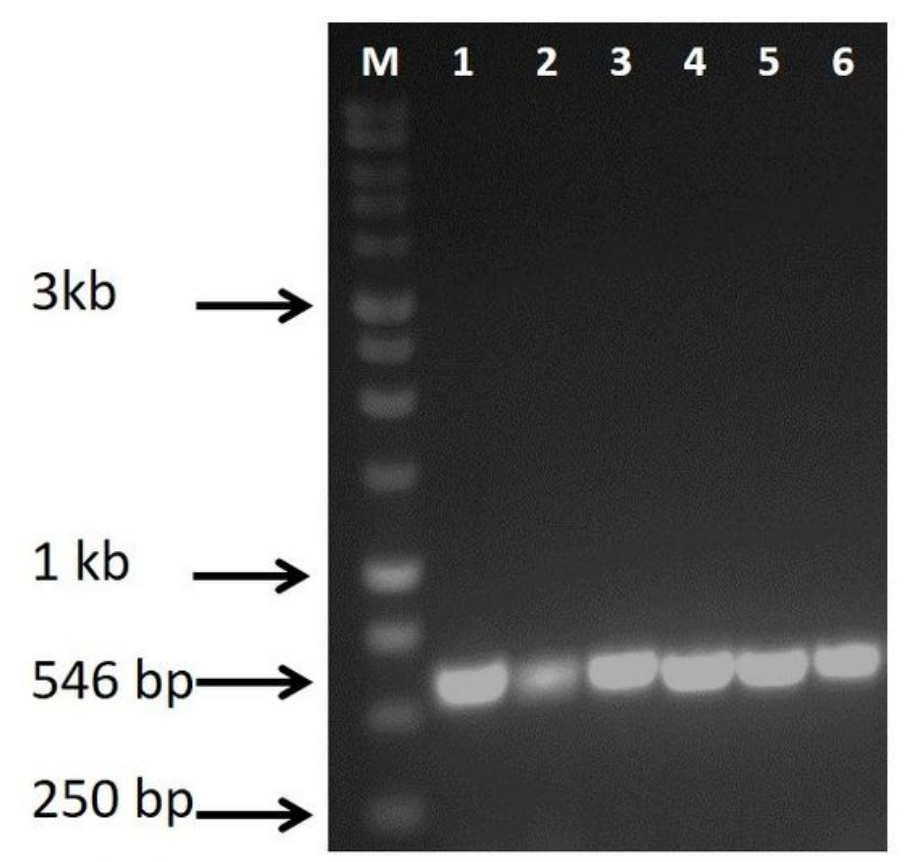

(A)

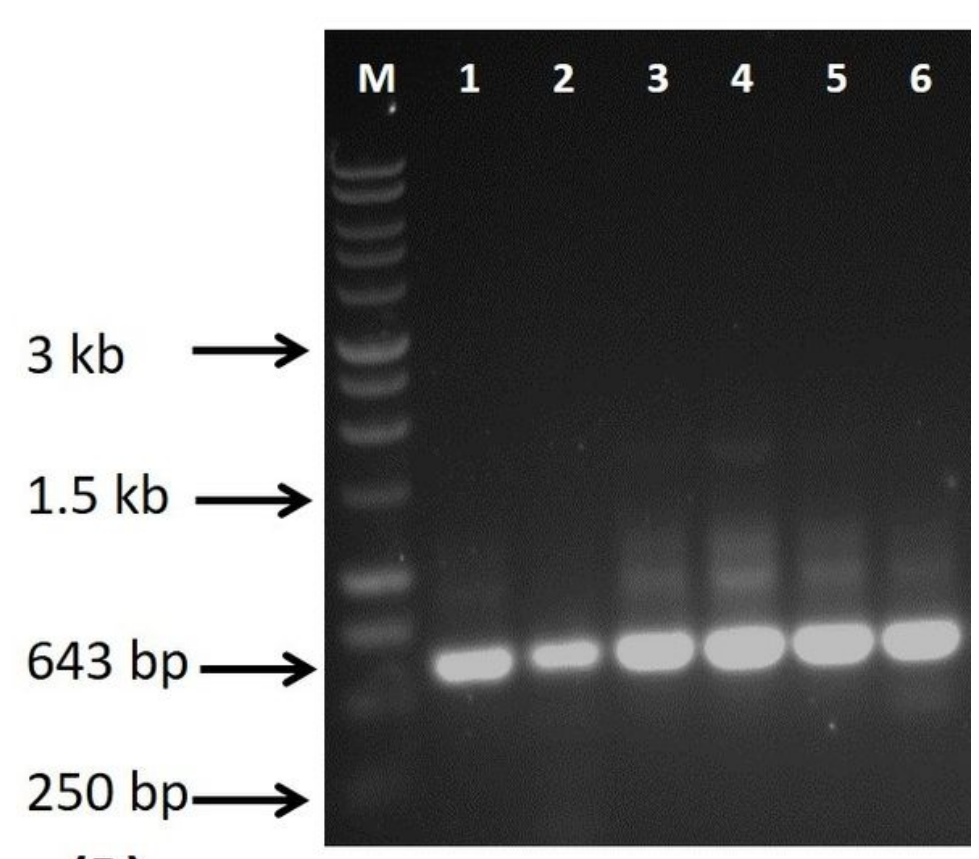

(B)

Figure 2

PCR based detection of transgenic tobacco plants having 35S-ASAL. (A) PCR amplification of full length asal, gene using ASAL-F3 and ASAL-R3 primer pair (product 546 bp). M: 1 kb DNA ladder. Lane\# 1-6: Transgenic tobacco lines LS-15, LS-17, LS-18, LS-20, LS-21, LS-25. (B) PCR amplification of promotergene (35S-ASAL) fragment using primer pair 35S-F1 and ASAL-R3 (product $643 \mathrm{bp}$ ). M: 1 kb DNA ladder. Lane\# 1-6: Transgenic tobacco lines, LS-15, LS-17, LS-18, LS-20, LS-21, LS-25.

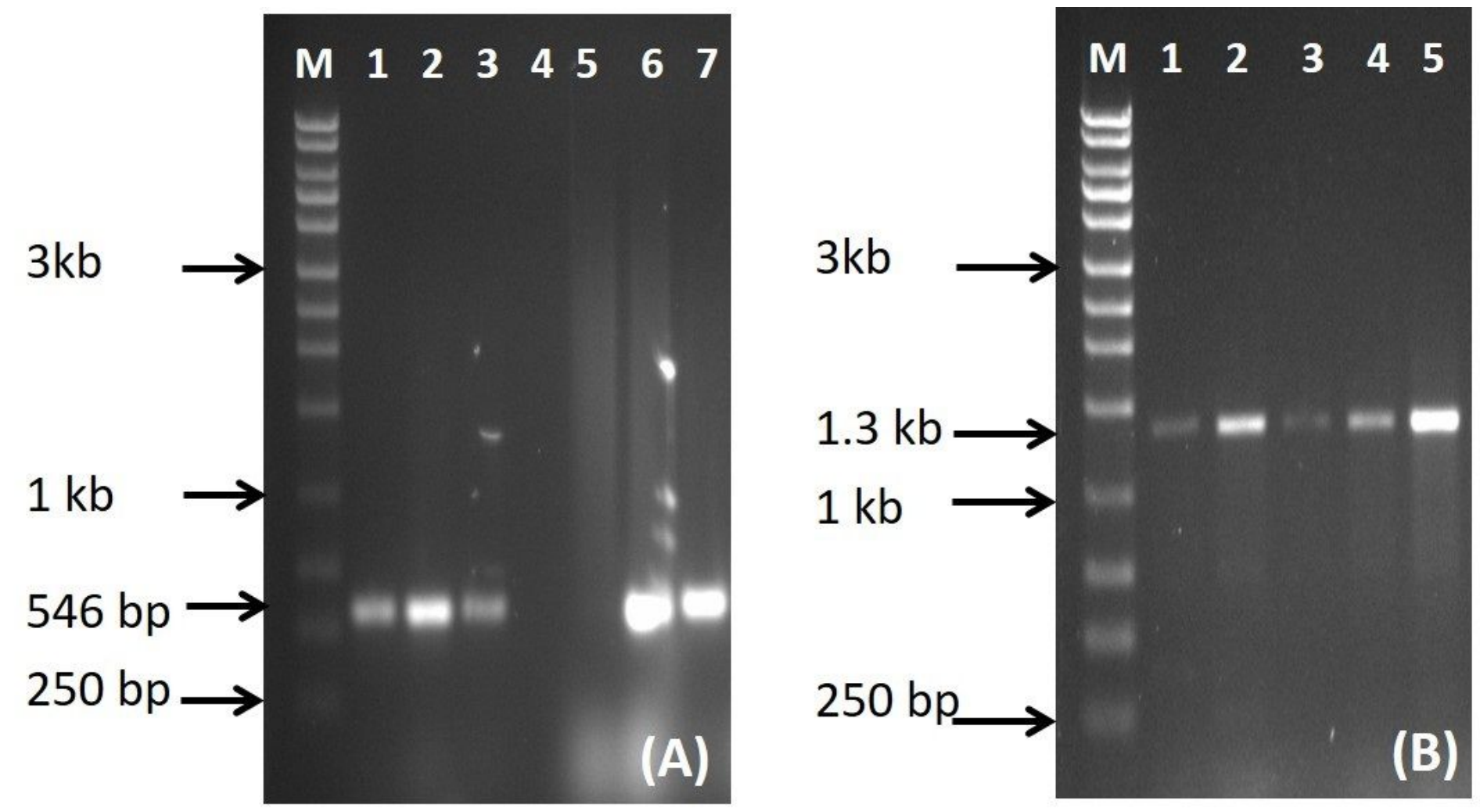




\section{Figure 3}

PCR based detection of transgenic tobacco plants having rolC-ASAL. (A) PCR amplification of asal, gene using ASAL-F3 and ASAL-R3 primer pair (product 546). M: 1 kb DNA ladder. Lane\# 1-7: Putative transgenic tobacco lines LR-1, LR-3, LR-7, LR-8, LR-9, LR-10, LR-12. (B) PCR amplification of promotergene (rolC-ASAL) fragment using rolC-F2 and ASAL-R3 (product $1.3 \mathrm{~kb}$ ). Lane\# 1-5: Transgenic tobacco lines LR-1, LR-3, LR-7, LR-10, LR-12.

$\begin{array}{llllllllll}M & 1 & 2 & 3 & P 1 & C & P 2 & 4 & 5 & M\end{array}$

\section{$10 \mathrm{~kb}$}

$3 \mathrm{~kb}$

\section{$250 \mathrm{bp}$}

\section{Figure 4}


Southern blot analysis to confirm integration of transgene in genomic DNA of tobacco plants restricted with EcoRI. M: 1 kb DNA ladder. P1: Plasmid (pGA482-35S-ASAL). P2: Plasmid (pGA482-rolC-ASAL). C: Restricted genomic DNA of non-transgenic tobacco. Lane \# 1-3: 35S-ASAL expressing tobacco lines, LS15, LS-18, and LS-21. Lane \# 4-5: rolC-ASAL expressing tobacco lines LR-10, and LR-12.

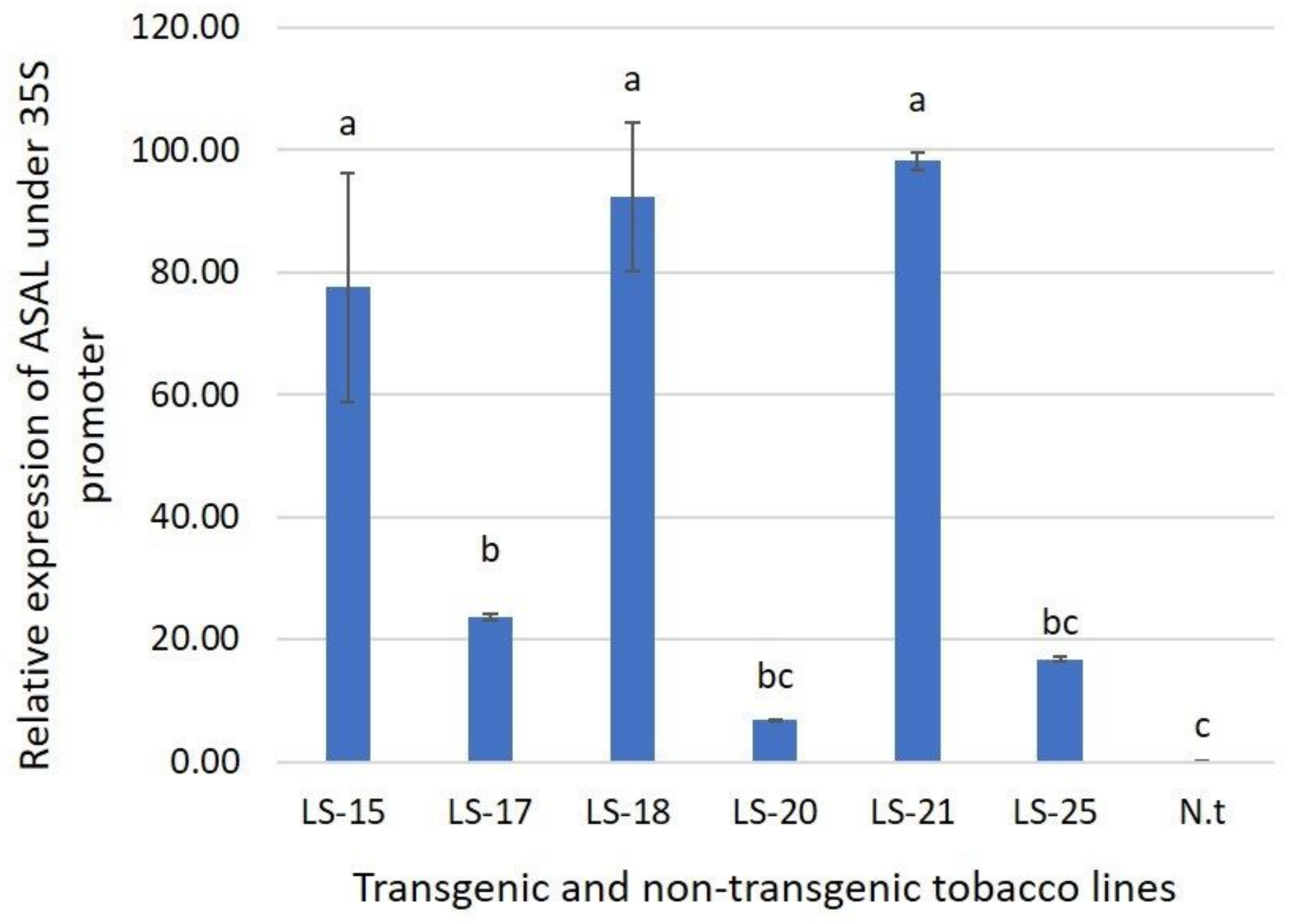

Figure 5

qRT-PCR for gene expression analysis of ASAL under 35S promoter in transgenic tobacco lines. LS-15, LS-17, LS-18, LS-20, LS-21 and LS-25: Transgenic tobacco lines expressing ASAL under 35S promoter. N.t: Non-transgenic tobacco line. Column height shows expression level of transcript, ASAL. Alphabets on error bars indicate significant differences of expression among transgenic and non-transgenic tobacco at $p<0.01$ using ANOVA followed by LSD; Mean \pm SE of $N=3$. 


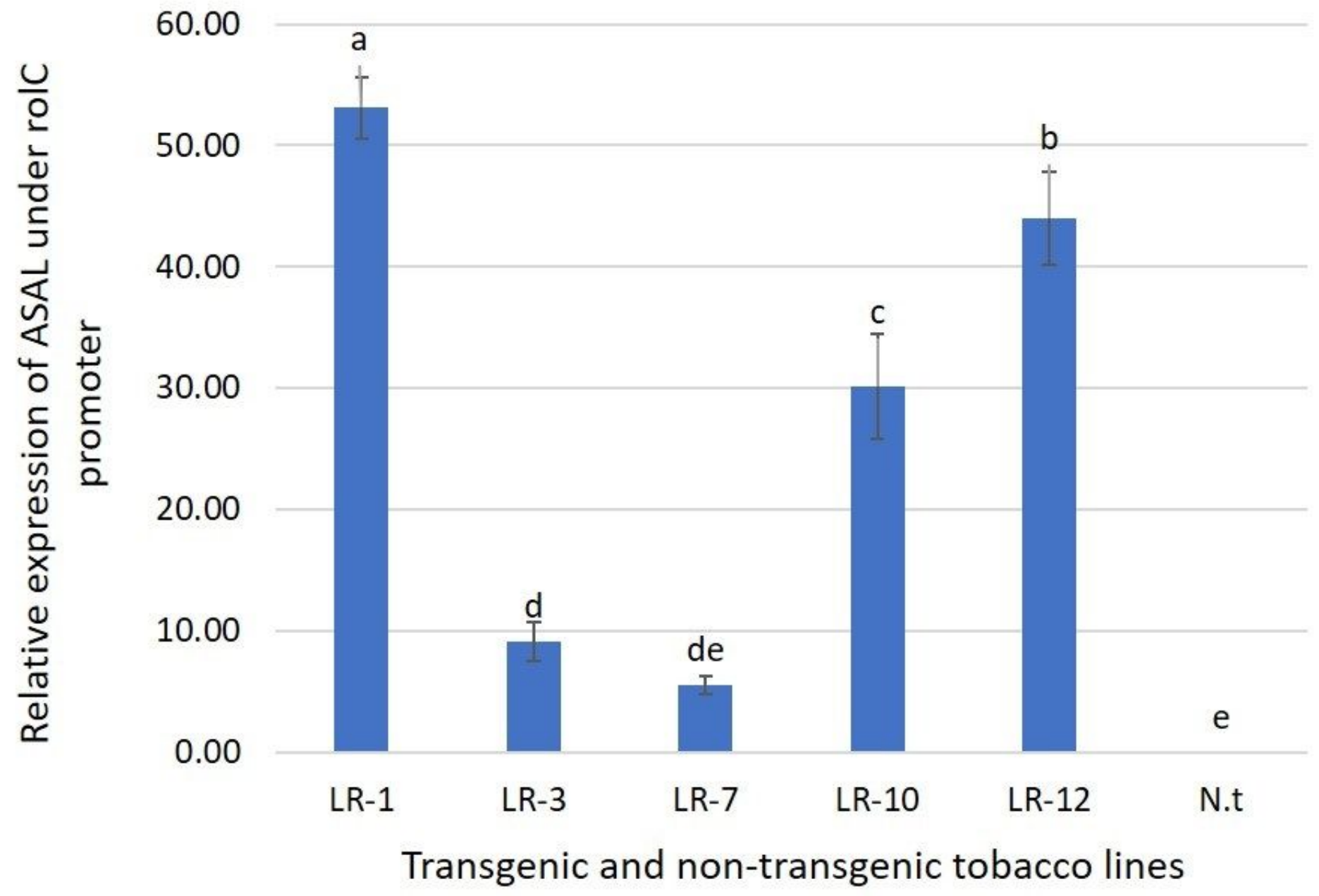

Figure 6

qRT-PCR for gene expression analysis of ASAL under rolC promoter in transgenic tobacco lines. LR-1, LR3, LR-7, LR-10 and LR-12: Transgenic tobacco lines expressing ASAL under rolC promoter. N.t: Nontransgenic tobacco lines. Column height shows expression level of transcript, ASAL. Alphabets on error bars indicate significant differences of expression among transgenic and non-transgenic tobacco at $p<0.01$ using ANOVA followed by LSD; Mean \pm SE of $N=3$. 


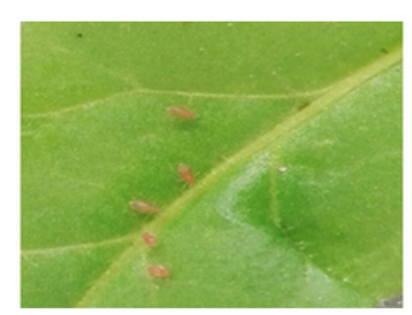

A

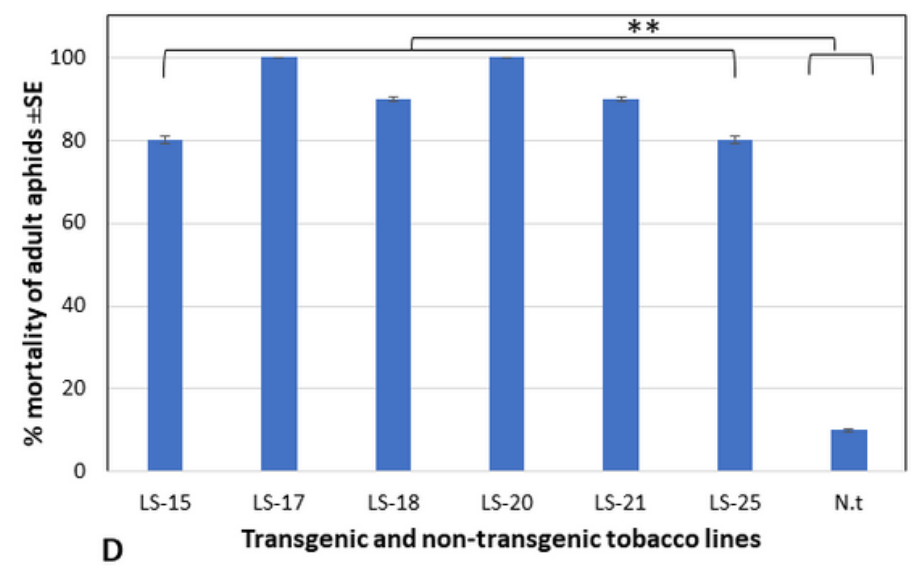

B
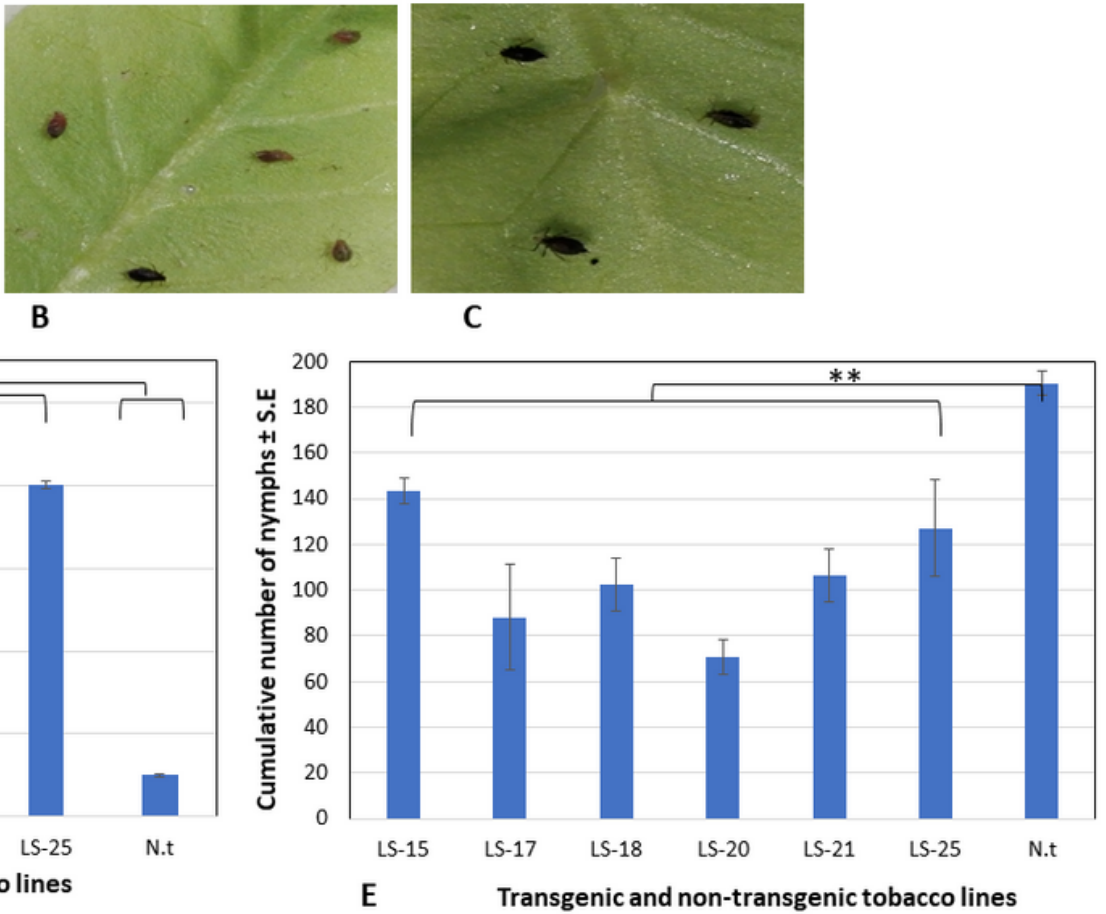

\section{Figure 7}

Aphid bioassay of transgenic tobacco lines expressing ASAL under 35 S promoter. (A) Adult aphids feeding on non-transgenic plants showed no mortality. (B-C) Aphid mortality during feeding on transgenic detached leaves. (D) Percent mortality of adult aphids on tobacco lines (LS-15, LS-17, LS-18, LS-20, LS21, and LS-25) versus control tobacco after every 24 hours for thirteen days. (E) Number of cumulative nymphs released by adult aphids from day 5-13 on transgenic tobacco lines (LS-15, LS-17, LS-18, LS-20, LS-21, and LS-25) versus control tobacco plants. Double steric represent the significant difference among 35S-ASAL tobacco lines and non-transgenic tobacco using Mann-Whitney U-test; Mean $\pm S E$ of $N=2$, **P $<0.01$. 

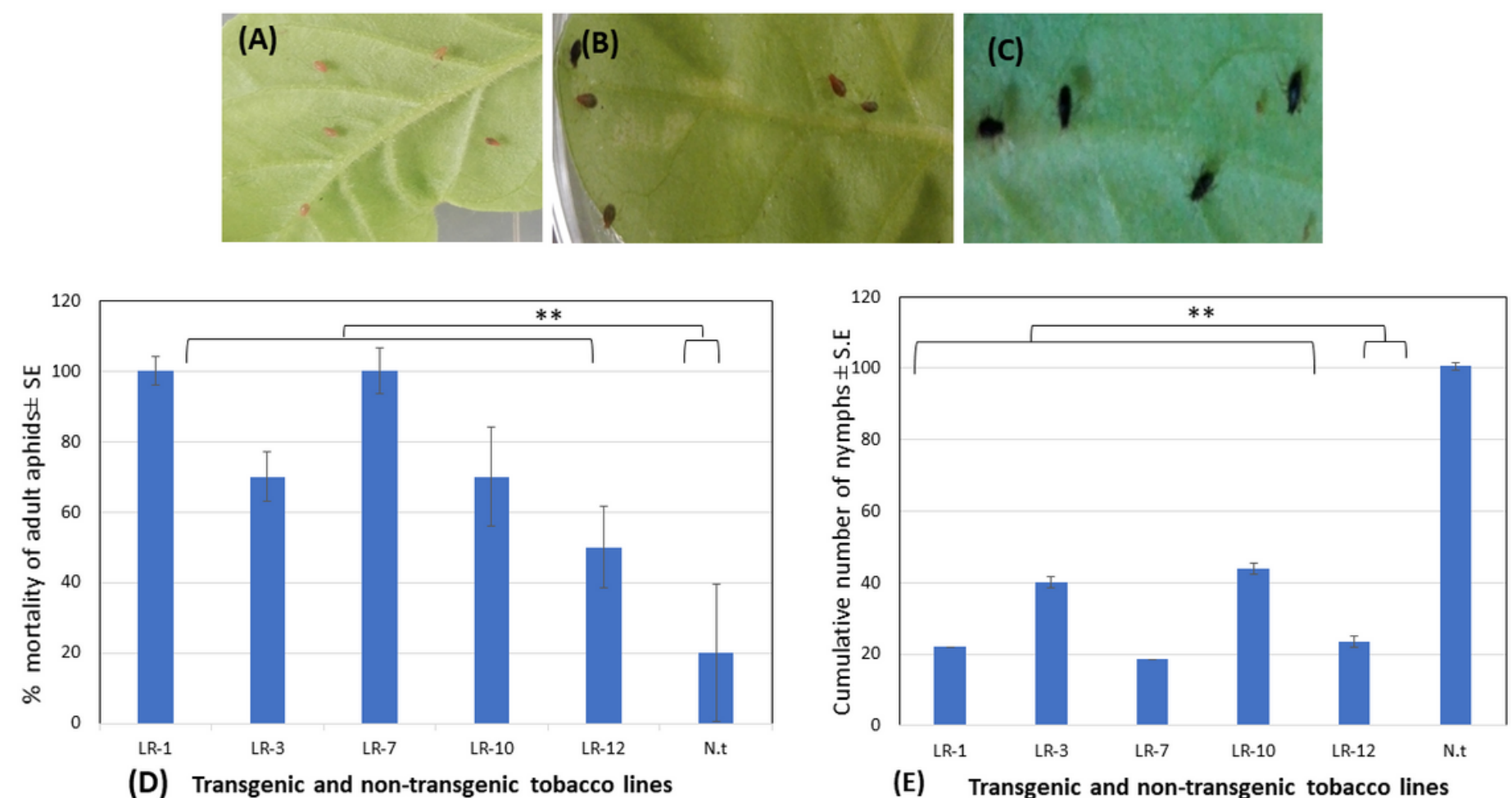

(E) Transgenic and non-transgenic tobacco lines

\section{Figure 8}

Aphid bioassay of transgenic tobacco lines expressing ASAL under rolC promoter. (A) Adult aphids feeding on non-transgenic plants showed no mortality. (B-C) Aphid mortality during feeding on transgenic detached leaves. (C) Percent mortality of ten adult aphids on each tobacco lines (LR-1, LR-3, LR-7, LR-10 and LR-12) versus control tobacco after every 24 hours for thirteen days. (D) Number of cumulative nymphs produced by adult aphids on transgenic tobacco lines (LR-1, LR-3, LR-7, LR-10 and LR-12) versus control tobacco plants from day 5-13 after 24 hours. Double steric show the significant difference among rolC-ASAL tobacco lines and non-transgenic tobacco using Mann-Whitney U-test; Mean $\pm S E$ of $N=2$, **P $<0.01$. 